\title{
Evaluation of Hydrogenated Amorphous Silicon Oxide Photo-Absorber from Quantum Efficiency in Thin-Film Solar Cell by Fourier Transform Photocurrent Spectroscopy
}

\author{
Nur Syazwana Abd Rahman, Kento Matsui, Shigeru Yamada and Takashi Itoh* \\ Department of Electrical, Electronic and Computer Engineering, Gifu University, Gifu 501-1193, Japan
}

We demonstrated evaluation of sub-gap state and gap-state defect in hydrogenated amorphous silicon oxide (a-SiOX:H) photo-absorber within solar cell structure from internal quantum efficiency $(I Q E)$ measured by Fourier transform photocurrent spectroscopy (FTPS). In IQE spectra for a-SiO $: \mathrm{H}$ thin-film solar cells, exponential tail and $I Q E$ corresponding to gap-state defect was observed. We also investigated lightinduced degradation in a-SiO $: H$ photo-absorber within solar cell structure by FTPS. IQE related to gap-state defect increased and conversion efficiency decreased by light irradiation, which corresponds to light-induced degradation. Urbach energy obtained from IQE spectra increased by light irradiation. [doi:10.2320/matertrans.MT-M2020379]

(Received December 14, 2020; Accepted May 6, 2021; Published June 25, 2021)

Keywords: gap-state defect, Fourier transform photocurrent spectroscopy, a-SiO ${ }_{x}: H$ thin-film solar cell, light-induced degradation

\section{Introduction}

The study on hydrogenated amorphous silicon oxide (a$\left.\mathrm{SiO}_{\mathrm{X}}: \mathrm{H}\right)$ films has already started in 1990s and Si-based thinfilm solar cells using p-type a-SiO $\mathrm{X}_{\mathrm{X}} \mathrm{H}$ as p-layer material have been developed. ${ }^{1,2)}$ The development of Si-based thinfilm solar cells using i-type a- $\mathrm{SiO}_{\mathrm{X}}: \mathrm{H}$ as i-layer material i.e. a-SiO ${ }_{\mathrm{X}}: \mathrm{H}$ thin-film solar cells has also started and few years later, conversion efficiency of $7.48 \%$ has been obtained in single junction a-SiO $\mathrm{X}_{\mathrm{X}}: \mathrm{H}$ thin-film solar cells. ${ }^{3)}$ To the best of our knowledge, nowadays, a stabilized conversion efficiency of around $12 \%$ has been obtained in triple junction thin-film solar cell using a-SiO ${ }_{\mathrm{X}}: \mathrm{H}$ thin-film solar cell as a top cell. ${ }^{4}$ However, the conversion efficiency is still far from that theoretically calculated efficiency based on ShockleyQueisser limit at the band gap energy of a-SiO ${ }_{\mathrm{X}}: \mathrm{H}$. It is well known that the main cause for low conversion efficiency of Si-based thin-film solar cells is high density of defect that act as a recombination center in the i-layer (i.e. photoabsorber layer) material. ${ }^{5)}$ To increase conversion efficiency of $\mathrm{a}-\mathrm{SiO}_{\mathrm{X}}: \mathrm{H}$ thin-film solar cells, it is necessary to decrease defect density in i-type a-SiO${ }_{X}: \mathrm{H}$ as i-layer layer material. Therefore, defect characterization in i-type $\mathrm{a}-\mathrm{SiO}_{\mathrm{X}}: \mathrm{H}$ is important to improve the conversion efficiency of the a$\mathrm{SiO}_{\mathrm{X}}: \mathrm{H}$ thin-film solar cells.

In hydrogenated amorphous silicon (a-Si:H) films, Sidangling bond forms defect state in the band gap (gap-state defect) that act as recombination center. There are several methods to characterize the gap-state defect in a-Si:H. The gap-state defect in a-Si:H is generally characterized using electron spin resonance (ESR). In the ESR measurement, neutral Si dangling bond is detected and the defect density (i.e. spin density owing to $\mathrm{Si}$ dangling bond) is determined. ${ }^{6,7)}$ The gap-state defect in a-Si:H is also characterized from optical absorption in lower-photon-energy region. Basically, an optical absorption in lower-photon-energy region is owing to the transition from (or to) the gap-state defect owing to the Si dangling bond in a-Si:H. Hence, by

*Corresponding author, E-mail: itoh@gifu-u.ac.jp measuring optical absorption coefficient spectra in lowerphoton-energy region, defect density in the a-Si:H films is estimated. The a-Si:H films have band-tail state in the band gap near the bottom of conduction band and the top of valence band. In a-Si:H thin-film solar cells, the band tail in a-Si:H i-layer is also affects the conversion efficiency. The band-tail state also evaluated by optical absorption coefficient spectra in photon-energy region below band gap energy of a-Si:H. There are several methods to measure optical absorption coefficient spectra in lower-photon-energy region such as photo-thermal deflection spectroscopy (PDS), ${ }^{8,9)}$ and constant photocurrent method (CPM). ${ }^{7,10)}$ Fourier transform photocurrent spectroscopy (FTPS) which is originated from CPM principle has been developed by M. Vanecek and A. Poruba as a method to measure optical absorption spectra in lower-photon-energy region. ${ }^{10,11)} \mathrm{We}$ have investigated the gap-state defect in $\mathrm{a}-\mathrm{SiO}_{\mathrm{X}}: \mathrm{H}$ films using ESR and FTPS. We reported previously that defect density (i.e. spin density owing to the Si dangling bond) was able to be estimated from optical absorption in lower-photon-energy region in $\mathrm{a}_{-} \mathrm{SiO}_{\mathrm{X}}: \mathrm{H}$ films. ${ }^{12)}$ In the characterization of defect in i-type Si-based films, the films deposited on flat substrate are usually used. On the other hand, in p-i-n type Si-based thin-film solar cells, p-layer is deposited on glass substrates coated with textured transparent conductive oxide (TCO), and photo-absorber layer (i.e. i-layer) is deposited on it. Therefore, the defect characterization in photo-absorber layer materials within solar cell structure is necessary. However, it is difficult to characterize defect in photo-absorber layer material within solar cell structure by ESR and PDS. On the other hand, FTPS is applicable to measure optical absorption of photo-absorber layer material within solar cell structure since optical absorption is obtained from photocurrent in FTPS. Furthermore, fast measurement of optical absorption is possible using FTPS. In a-Si:H thin-film solar cells, defect characterization in i-layer has been conducted using FTPS. ${ }^{10,13-15)}$ Therefore, it is expected that defect characterization in $\mathrm{i}$-layer is possible in $\mathrm{a}-\mathrm{SiO}_{\mathrm{X}}: \mathrm{H}$ thin-film solar cells. However, the characterization of $\mathrm{a}-\mathrm{SiO}_{\mathrm{X}}: \mathrm{H}$ thin-film solar cells by FTPS has not been reported. Although defect 
characterization in i-layer in a-Si:H thin-film solar cells has been carried out previously as mentioned above, those in $\mathrm{a}-\mathrm{SiO}_{\mathrm{X}}: \mathrm{H}$ thin-film has not been carried out.

The highlight of this work is an application of FTPS to a-SiO ${ }_{X}: H$ thin-film solar cells. Conventionally, an analysis by FTPS is carried out based on optical absorption coefficient spectra as the previous works on a-Si:H and a-SiO $\mathrm{X}_{\mathrm{X}}: \mathrm{H}$ films. However, for photo-absorber layer within solar cell structures, it is not easy to analyze optical absorption directly. Since photo-absorber layer material is deposited on textured glass substrate and sandwiched between $\mathrm{p}$ - and n-layer materials in Si-based thin-film solar cell devices. In lowerphoton-energy region, internal quantum efficiency $(I Q E)$ of Si-based thin-film solar cells would be almost the same as the product of the optical absorption coefficient and the i-layer thickness as explained later. Therefore, we tried to evaluate from IQE spectra. In a-SiO $\mathrm{X}: \mathrm{H}$ films, band gap energy, defect density, and band-tail state depends on $\mathrm{O}$ composition ratio. ${ }^{12)}$ Unlike a-Si:H thin-film solar cells, in $\mathrm{a}-\mathrm{SiO}_{\mathrm{X}}: \mathrm{H}$ thin-film solar cells, it is necessary to investigated the change in those due to $\mathrm{O}$ composition ratio in a-SiO${ }_{X}: H$ i-layer. Therefore, in this study, IQE spectra for $\mathrm{a}-\mathrm{SiO}_{\mathrm{X}}: \mathrm{H}$ thin-film solar cells with various $\mathrm{O}$ composition ratios were measured by FTPS. We tried evaluation of band-tail state and gap-state defect in $\mathrm{a}-\mathrm{SiO}_{\mathrm{X}}: \mathrm{H}$ i-layer within solar cell structure from IQE spectra in lower-photon-energy region and compared with those in a-Si: $\mathrm{O}_{\mathrm{X}}: \mathrm{H}$ films. Also, light-induced degradation in $\mathrm{a}-\mathrm{SiO}_{\mathrm{X}}: \mathrm{H}$ i-layer within solar cell structure has been investigated using IQE spectra measured by FTPS.

\section{Experimental Procedure}

\subsection{Samples}

Solar cell samples used in this work were single-junction p-i-n type a-SiO $\mathrm{X}: \mathrm{H}$ thin-film solar cells. The solar cell samples were deposited by plasma enhanced chemical vapor deposition (PECVD) on glass substrates coated with textured transparent conductive oxide (TCO). In the solar cell samples, p-type hydrogenated amorphous silicon carbide $\left(\mathrm{a}-\mathrm{SiC}_{\mathrm{X}}: \mathrm{H}\right)$ and $\mathrm{n}$-type hydrogenated nanocrystalline silicon oxide $\left(\mathrm{nc}-\mathrm{SiO}_{\mathrm{X}}: \mathrm{H}\right)$ were used as the $\mathrm{p}$ - and n-layer materials, respectively. The deposition conditions and thickness of $\mathrm{p}$ - and n-layer were same in all the solar cell samples. The i-type a-SiO $\mathrm{X}_{\mathrm{X}}: \mathrm{H}$ layer with various $\mathrm{O}$ composition ratios $\mathrm{O} /(\mathrm{Si}+\mathrm{O})$ were deposited by very high frequency PECVD (VHF-PECVD). The frequency was $54.24 \mathrm{MHz}$ in VHFPECVD. The substrate temperature was $200^{\circ} \mathrm{C}$. A gas mixture of $\mathrm{SiH}_{4}, \mathrm{CO}_{2}$, and $\mathrm{H}_{2}$ was used as source gas. The $\mathrm{O} /(\mathrm{Si}+\mathrm{O})$ was varied by the $\mathrm{CO}_{2}$ gas flow ratio $\mathrm{CO}_{2} /$ $\left(\mathrm{SiH}_{4}+\mathrm{CO}_{2}\right)$. The $\mathrm{O} /(\mathrm{Si}+\mathrm{O})$ of the i-layer was from 8.7 to $10.2 \%$. Thickness of i-layer in the solar cell samples was $0.2 \mu \mathrm{m}$. For comparison, $\mathrm{a}_{-\mathrm{SiO}} \mathrm{X}: \mathrm{H}$ films were also deposited on sapphire substrates with exactly the same condition of the i-layer. Thickness of the film samples was $0.83 \sim 1.47 \mu \mathrm{m}$.

\subsection{Evaluation}

X-ray photoelectron spectroscopy (XPS) was carried out using ULVAC-PHI Quantera-SXM. The O/(Si + O) was estimated from $\mathrm{Si}-2 \mathrm{p}$ and O-1s XPS peaks in the film samples.
FTPS was carried out in order to measure external quantum efficiency $(E Q E)$ for solar cell samples and in order to measure optical absorption coefficient spectra in lower-photon-energy region for film samples. In FTPS measurement, Fourier transform infrared (FT-IR) spectrometer (Thermofisher Nicolet iS50R) was used as an interferometer. The solar cell and film samples were connected into an electrical circuit with current preamplifier (Stanford Research SR570) as the external detector. In the FTPS measurement for the solar cell samples, voltage was not applied to the solar cell samples. On the other hand, in the FTPS measurement for the film samples, the voltage of $80 \mathrm{~V}$ was applied to the Al gap electrode which was evaporated on the film samples. EQE spectra for the solar cell samples were also measured by a conventional technique using EIKO SRM-006. Optical reflectance spectra for the solar cell samples were measured using JASCO V-670 with an integrating sphere. Optical transmittance spectra for the film samples were measured using Perkin Elmer Lambda 950. Optical absorption coefficient spectra in the higherphoton-energy region for the film samples were obtained from the optical transmittance spectra.

The current-voltage (I-V) characteristics for the solar cell samples were measured at room temperature in air under light irradiation of AM-1.5 light (power density of $100 \mathrm{~mW} / \mathrm{cm}^{2}$ ) using a solar simulator. From the I-V characteristics, conversion efficiency $\eta$ was obtained. The photoconductivity $\sigma_{\mathrm{P}}$ of the film samples was measured at room temperature in air using $\mathrm{Al}$ gap electrode. In the $\sigma_{\mathrm{P}}$ measurement, $\mathrm{AM}-1.5$ light $\left(100 \mathrm{~mW} / \mathrm{cm}^{2}\right)$ was used as the irradiation light.

Spin density was determined from electron spin resonance (ESR) spectra for the film samples. The ESR spectra were measured at room temperature using JEOL JES-FA100 with $\mathrm{X}$-band $(9.4 \mathrm{GHz})$. The modulated magnetic field and microwave power were $0.3 \mathrm{mT}$ and $0.5 \mathrm{~mW}$, respectively. In the ESR measurement, five films with same $\mathrm{O} /(\mathrm{Si}+\mathrm{O})$ were used without peeling off substrates. Then, the volume of the film samples used in ESR measurement was from $0.85 \times$ $10^{-3}$ to $1.49 \times 10^{-3} \mathrm{~cm}^{3}$. The spin density was determined by comparison with the ESR signal of strong coal whose spin density was known.

\section{Results and Discussions}

\subsection{IQE spectra for $\mathrm{a}-\mathrm{SiO}_{\mathrm{X}}: \mathrm{H}$ thin-film solar cells measured by FTPS}

In FTPS measurement for solar cell samples, absolute value of $\operatorname{EQE}(E)$ at photon energy $E$ was not obtained. Therefore, the EQE spectrum measured by FTPS was calibrated by fitting it to that measured by the conventional method. IQE spectra were obtained from the calibrated EQE spectrum measured by FTPS and EQE spectrum measured by the conventional method using optical reflectance spectra for the solar cell sample. Figure 1 shows typical IQE spectra for the solar cell sample measured by FTPS and conventional method. The $\mathrm{O} /(\mathrm{Si}+\mathrm{O})$ of the i-layer in the solar cell sample was $9.2 \%$. The curves A (solid curve) and B (dashed curve) represent the spectra measured by FTPS and the conventional method, respectively. In Fig. 1, the spectrum measured by FTPS shows good agreement with that 


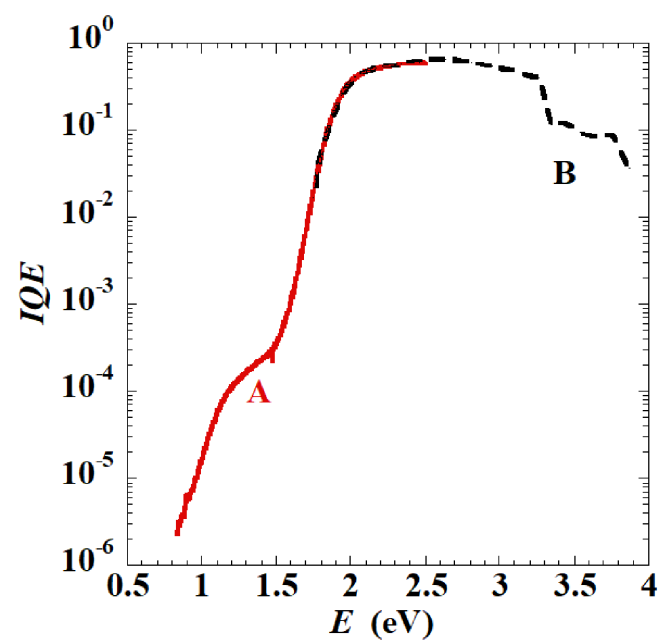

Fig. 1 Typical IQE spectra of $\mathrm{a}-\mathrm{SiO}_{\mathrm{X}}: \mathrm{H}$ thin-film solar cell measured by FTPS and conventional method. The $\mathrm{O} /(\mathrm{Si}+\mathrm{O})$ of the i-layer was $9.2 \%$ The curves A (solid curve) and B (dashed curve) represent IQE spectra measured by FTPS and conventional method, respectively.

measured by the conventional method. The detection limit of the IQE measurement by FTPS was about 4 orders of magnitude smaller than that measured by the conventional method. This result indicates that a high-sensitive IQE measurement is possible by FTPS.

Generally, in semiconductor material, band gap energy $E_{\mathrm{O}}$ is estimated from optical absorption coefficient spectrum, electrical conductivity, ${ }^{16}$ photoconductivity, ${ }^{17)}$ and Hall effect. ${ }^{18)} E_{\mathrm{O}}$ of amorphous semiconductor films such as a$\mathrm{Si}: \mathrm{H}$ is estimated from Tauc's plot using optical absorption coefficient spectrum. ${ }^{12,19)}$ In techniques mentioned above, however, estimation of $E_{\mathrm{O}}$ is usually done using a film sample. In compound thin-film solar cells, the $E_{\mathrm{O}}$ of the photo-absorber layer (i-layer) material is estimated from IQE spectra. In the estimation from IQE spectra for compound thin-film solar cells, the peak energy of the derivative of $\operatorname{IQE}(E)$ with respect to $E, d I Q E(E) / d E$, is determined as $E_{\mathrm{O}}$. Therefore, the $E_{\mathrm{O}}$ of the i-layer in a-SiO $\mathrm{X}: \mathrm{H}$ thin-film solar cells were estimated from IQE spectra using above method. Figure 2 shows the dependence of $E_{\mathrm{O}}$ on $\mathrm{O} /(\mathrm{Si}+\mathrm{O})$. For comparison, $E_{\mathrm{O}}$ of film samples were also shown by the triangles in Fig. 2. The $E_{\mathrm{O}}$ of the film samples were determined from Tauc's plot using optical absorption coefficient spectra in higher-photon-energy region obtained from optical transmittance spectra. In Fig. 2, the $E_{\mathrm{O}}$ determined from $d I Q E(E) / d E$ increased with increasing the $\mathrm{O} /(\mathrm{Si}+\mathrm{O})$ from $8.7 \%$ to $10.2 \%$. Although the value of $E_{\mathrm{O}}$ determined from $d I Q E(E) / d E$ was not exactly same as that determined from Tauc's plot, the $\mathrm{O} /(\mathrm{Si}+\mathrm{O})$ dependence of $E_{\mathrm{O}}$ determined from $d \operatorname{IQE}(E) / d E$ in solar cell samples showed good agreement with that determined from Tauc's plot in film samples. This result indicates that estimation of $E_{\mathrm{O}}$ in a-SiO $\mathrm{X}_{\mathrm{X}}: \mathrm{H}$ i-layer within solar cell samples is possible from IQE spectra.

$\operatorname{IQE}(E)$ is given as following equation.

$$
\operatorname{IQE}(E)=1-\frac{\exp \{-\alpha(E) d\}}{\alpha(E) L+1}
$$

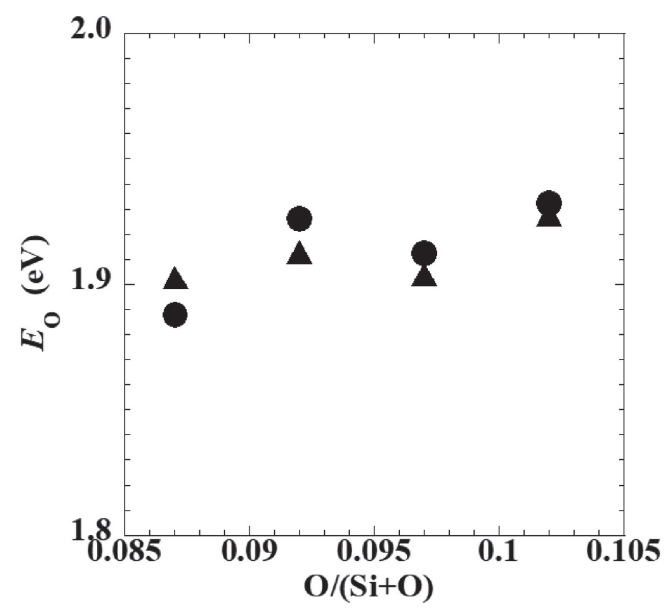

Fig. 2 Dependence of band gap energy $E_{\mathrm{O}}$ on $\mathrm{O}$ composition ratio $\mathrm{O} /$ $(\mathrm{Si}+\mathrm{O})$. Circles and triangles represent $E_{\mathrm{O}}$ values obtained from peak derivative of $\operatorname{IQE}(E)$ with a respect to $E$ in solar cell samples and obtained from Tauc's plot in film samples, respectively.

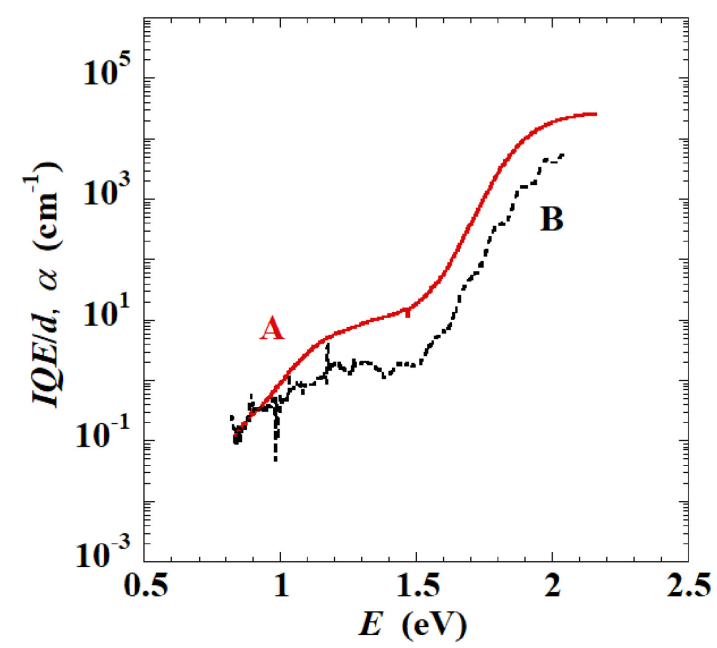

Fig. 3 Typical IQE/d spectrum for $\mathrm{a}-\mathrm{SiO}_{\mathrm{X}}: \mathrm{H}$ thin-film solar cell and optical absorption coefficient spectrum for a-SiO $\mathrm{X}: \mathrm{H}$ film. The $\mathrm{O} /$ $(\mathrm{Si}+\mathrm{O})$ of the i-layer in solar cell sample and film sample was $9.2 \%$. The curves A (solid curve) and B (dashed curve) represent IQE/d spectrum for the solar cell sample and optical absorption coefficient spectrum for the film sample, respectively.

Here, $\alpha(E)$ and $L$ are optical absorption coefficient of i-layer (that is a- $\mathrm{SiO}_{\mathrm{X}}: \mathrm{H}$ ) at $E$ and diffusion length of minority carrier, respectively. The $d$ is space charge region width, that is $\mathrm{i}$-layer thickness in $\mathrm{a}-\mathrm{SiO}_{\mathrm{X}}: \mathrm{H}$ thin-film solar cells. In lowerphoton-energy region corresponding to band-tail state and gap-state defect, $\operatorname{IQE}(E)$ of a-SiO ${ }_{\mathrm{X}}: \mathrm{H}$ thin-film solar cells can be approximated to

$$
\operatorname{IQE}(E) \approx \alpha(E) d,
$$

because $\alpha(E) d \ll 1$ and $\alpha(E) L \ll 1$. According to above approximation, $\operatorname{IQE}(E) / d$ would be almost the same as $\alpha(E)$ in lower-photon-energy region. Therefore, we compared IQE/d spectrum for solar cell sample and optical absorption coefficient spectrum for film sample. Figure 3 shows IQE/d spectrum for the solar cell sample and optical absorption coefficient spectrum for the film sample. In both of the film sample and the i-layer of the solar cell sample, the $\mathrm{O} /$ $(\mathrm{Si}+\mathrm{O})$ was $9.2 \%$. The curves $\mathrm{A}$ (solid curve) and $\mathrm{B}$ 
(dashed curve) are IQE/d spectrum for the solar cell sample and optical absorption coefficient spectrum for the film sample, respectively. The shape of IQE/d spectrum was similar to that of the optical absorption coefficient spectrum. The value of $\operatorname{IQE}(E) / d$, however, was larger than that of $\alpha(E)$. There were two possibilities for the difference in the value between $\operatorname{IQE}(E) / d$ and $\alpha(E)$. One is error in approximation. As explained above, $\operatorname{IQE}(E) / d$ is approximated to $\alpha(E)$ in the case of $\alpha(E) d \ll 1$ and $\alpha(E) L \ll 1$. Therefore, $\operatorname{IQE}(E) / d$ is not exactly the same as $\alpha(E)$. The other is difference in carrier transport. In photocurrent transport in film samples, electrons generated by light irradiation is dominant carrier. On the other hand, not only electrons but also holes play as carrier in photocurrent transport in solar cell samples. Therefore, the value of $\operatorname{IQE}(E) / d$ was larger than that of $\alpha(E)$.

In the optical absorption coefficient spectrum, $\alpha(E)$ increased exponentially with increasing $E$ from $1.52 \mathrm{eV}$ to $1.86 \mathrm{eV}$. Optical absorption in this photon energy region is related to band-tail state and is called an exponential tail. The exponential tail is related to band-tail state in band gap near bottom of conduction band and top of valence band. Usually, the exponential tail is evaluated using Urbach energy $E_{\mathrm{U}}$ which is the parameter related to structural randomness. The optical absorption coefficient $\alpha_{\exp }(E)$ at $E$ in the exponential tail region is written by

$$
\alpha_{\exp }(E)=C_{\alpha} \cdot \exp \left(\frac{E}{E_{\mathrm{U}}}\right)
$$

where $C_{\alpha}$ is a constant. ${ }^{20)}$ In film samples, $E_{\mathrm{U}}$ and $C_{\alpha}$ are obtained from the fitting of eq. (3) to optical absorption coefficient spectra in the exponential tail region. In the IQE/d spectrum, $\operatorname{IQE}(E) / d$ also increased exponentially with increasing $E$ from $1.5 \mathrm{eV}$ to $1.86 \mathrm{eV}$. Therefore, it is expected that the $E_{\mathrm{U}}$ of i-layer is obtained from fitting of following eq. $\left(3^{\prime}\right)$ to IQE/d spectra in the exponential tail region.

$$
I Q E_{\exp }(E) / d=C_{\mathrm{IQE} / \mathrm{d}} \cdot \exp \left(\frac{E}{E_{\mathrm{U}}}\right)
$$

where $I Q E_{\text {exp }}(E)$ is internal quantum efficiency at $\mathrm{E}$ in the exponential tail region and $C_{\mathrm{IQE} / \mathrm{d}}$ is a constant. Figure 4 shows the dependence of $E_{\mathrm{U}}$ on the $E_{\mathrm{O}}$. Here, the $E_{\mathrm{O}}$ was determined from Tauc's plot in the film samples. Circles and triangles represent $E_{\mathrm{U}}$ obtained from IQE/d spectra for solar cell samples and obtained from optical absorption coefficient spectra for film samples, respectively. In Fig. 4, the $E_{\mathrm{U}}$ obtained from optical absorption coefficient spectra increased with increasing $E_{\mathrm{O}}$. The $E_{\mathrm{U}}$ obtained from IQE/d spectra also increased with the $E_{\mathrm{O}}$. This result suggests that the IQE/d spectrum in photon energy region from $1.5 \mathrm{eV}$ to $1.86 \mathrm{eV}$ is related to the band-tail state in i-layer. Based on this result, exponential tail in i-layer can be evaluated from IQE/d spectra for $\mathrm{a}-\mathrm{SiO}_{\mathrm{X}}: \mathrm{H}$ thin-film solar cells.

In both of the optical absorption coefficient and IQE/d spectra shown in Fig. 3, the slope of spectrum changed at $E$ near $1.5 \mathrm{eV}$. In the optical absorption coefficient spectrum for film sample, the optical absorption in the photon energy region below $1.5 \mathrm{eV}$ is related to gap-state defect in a$\mathrm{SiO}_{\mathrm{X}}: \mathrm{H}$. In a-SiO $\mathrm{X}: \mathrm{H}$ films, spin density owing to the $\mathrm{Si}$ dangling bond defect is estimated from the optical absorption

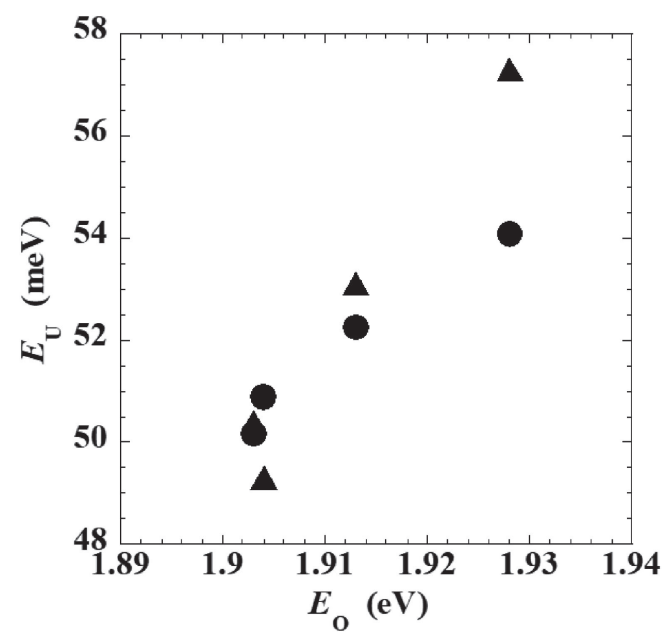

Fig. 4 Dependence of Urbach energy, $E_{\mathrm{U}}$ on band gap energy $E_{\mathrm{O}}$. Circles and triangles were $E_{\mathrm{U}}$ values obtained from IQE/d spectra for the solar cell samples and obtained from optical absorption spectra for the film samples, respectively.

related to gap-state defect. ${ }^{12)}$ Therefore, it is expected that spin density owing to Si dangling bond defect in i-layer is estimated from the IQE/d spectra for the solar cell samples. The optical absorption coefficient $\alpha_{\mathrm{def}}(E)$ related to gap-state defect is given by

$$
\alpha_{\mathrm{def}}(E)=\alpha(E)-\alpha_{\mathrm{exp}}(E) .
$$

The relationship between spin density $N_{\mathrm{S}}$ due to Si dangling bond and $\alpha_{\text {def }}(E)$ is given by

$$
N_{S}=K_{\alpha} \cdot A_{\alpha},
$$

where $K_{\alpha}$ is a correlation factor. The $A_{\alpha}$ in eq. (5) is the integrated $\alpha_{\text {def }}(E)$ as following eq. (6).

$$
A_{\alpha}=\int \alpha_{\mathrm{def}}(E) d E
$$

If the $\operatorname{IQE}(E) / d$ at $E$ below $1.5 \mathrm{eV}$ is related to gap-state defect in i-layer, $N_{\mathrm{S}}$ would be estimated from $\operatorname{IQE}(E) / d$ related to gap-state defect by the same method as film samples. In the IQE/d spectrum, eqs. (4) and (6) are rewritten as follows.

$$
\begin{aligned}
& I Q E_{\mathrm{def}}(E) / d=I Q E(E) / d-I Q E_{\mathrm{exp}}(E) / d \\
& A_{\mathrm{IQE} / \mathrm{d}}=\int I Q E_{\mathrm{def}}(E) / d d E
\end{aligned}
$$

Here, $I Q E_{\text {def }}(E)$ is internal quantum efficiency at $E$ related gap-state defect. Therefore, the $A_{\mathrm{IQE} / \mathrm{d}}$ was compared to the $A_{\alpha}$. Figure 5 shows the $E_{\mathrm{O}}$ dependence of the $A_{\mathrm{IQE} / \mathrm{d}}$ obtained from IQE/d spectra for solar cell samples and the $A_{\alpha}$ obtained from optical absorption coefficient spectra for film samples. Here, the $E_{\mathrm{O}}$ was determined from Tauc's plot in film samples. Circles and triangles represent $A_{\mathrm{IQE} / \mathrm{d}}$ and $A_{\alpha}$, respectively. The values of $A_{\mathrm{IQE} / \mathrm{d}}$ and $A_{\alpha}$ depend on the photon energy width to integrate. Therefore, the photon energy width to integrate was fixed at $0.77 \mathrm{eV}$. In the case of film samples, the $A_{\alpha}$ increased with increasing $E_{\mathrm{O}}$. Although the change in $A_{\mathrm{IQE} / \mathrm{d}}$ was small, the $A_{\mathrm{IQE} / \mathrm{d}}$ showed the tendency to increase with increasing $E_{\mathrm{O}}$ in the case of solar 


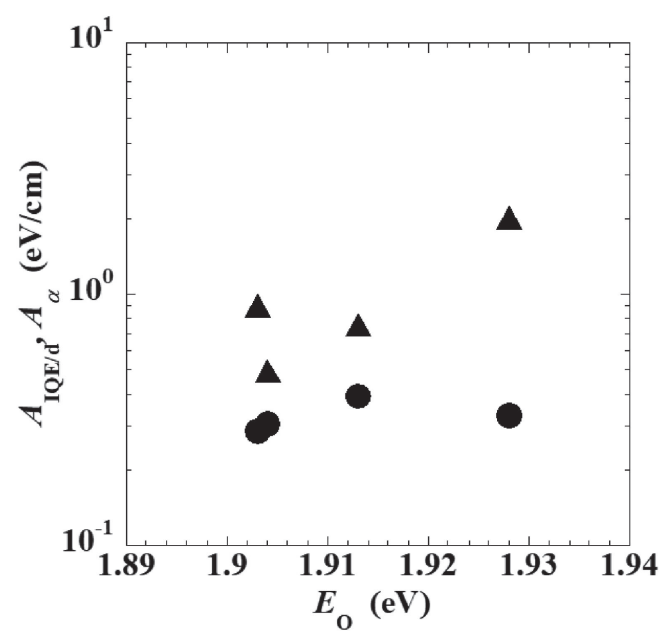

Fig. 5 Dependence of $A_{\mathrm{IQE} / \mathrm{d}}$ and $A_{\alpha}$ on band gap energy $E_{\mathrm{O}}$. The $E_{\mathrm{O}}$ was determined from Tauc's plot in film samples. Circles and triangles were $A_{\mathrm{IQE} / \mathrm{d}}$ obtained from IQE/d spectra and $A_{\alpha}$ obtained from optical absorption spectra, respectively

cell samples. This result suggests that the IQE/d spectrum at $E$ below $1.5 \mathrm{eV}$ shown in Fig. 3 would be related to gap-state defect. Although the $A_{\mathrm{IQE} / \mathrm{d}}$ was smaller than the $A_{\alpha}$, it would be possible to evaluate gap-state defect in a-SiOX:H i-layer within solar cell structure regardless of $\mathrm{O} /(\mathrm{Si}+\mathrm{O})$.

\subsection{Change in $\mathrm{IQE} / \mathrm{d}$ spectrum for $\mathrm{a}-\mathrm{SiO}_{\mathrm{X}}: \mathrm{H}$ thin-film solar cell by light irradiation}

Light-induced degradation occurs in a-Si:H, which phenomenon is well known as Staebler-Wronski effect. ${ }^{21)} \mathrm{Si}$ dangling bonds are created by irradiation of light with photon energy over the band gap energy in a-Si:H. As the results, spin density owing to $\mathrm{Si}$ dangling bond increases and electrical conductivity decreases by light irradiation. ${ }^{22,23)}$ Also, it was reported that light-induced degradation occurred in $\mathrm{a}-\mathrm{SiO}_{\mathrm{X}}: \mathrm{H}$ films. ${ }^{24)}$ As suggested above, exponential tail and gap-state defect in i-layer would be evaluated from IQE/d spectra in the lower-photon-energy region. Therefore, we tried to investigate light-induced degradation in i-layer within $\mathrm{a}-\mathrm{SiO}_{\mathrm{X}}: \mathrm{H}$ thin-film solar cell by FTPS. As evaluation for solar cell sample, I-V characteristics and FTPS measurements were performed. Light irradiation was conducted at room temperature in air using AM-1.5 light $\left(100 \mathrm{~mW} / \mathrm{cm}^{2}\right)$. From I-V characteristics, the measurements and light irradiation were conducted repeatedly. Here, total light irradiation time was defined as light irradiation time.

Figure 6 shows the change of IQE/d spectra for the solar cell sample by light irradiation. The spectra A (dashed curve) and B (solid curve) are IQE/d spectra before and after light irradiation, respectively. The $\mathrm{O} /(\mathrm{Si}+\mathrm{O})$ of the i-layer in the solar cell sample was $9.2 \%$. The light irradiation time was $240 \mathrm{~min}$. In Fig. 6, the $\operatorname{IQE}(E) / d$ at $E$ below $1.59 \mathrm{eV}$ increased by the light irradiation. The $A_{\mathrm{IQE} / \mathrm{d}}$ was obtained from each IQE/d spectrum at different light irradiation times. The change in $A_{\mathrm{IQE} / \mathrm{d}}$ with light irradiation time was investigated. Here, the value of $A_{\mathrm{IQE} / \mathrm{d}}$ depends on the integral photon energy range. Therefore, integral photon energy range was fixed between $0.82 \mathrm{eV}$ and $1.59 \mathrm{eV}$. Figure 7 shows the dependence of the $A_{\mathrm{IQE} / \mathrm{d}}$ and conversion efficiency $\eta$ on the

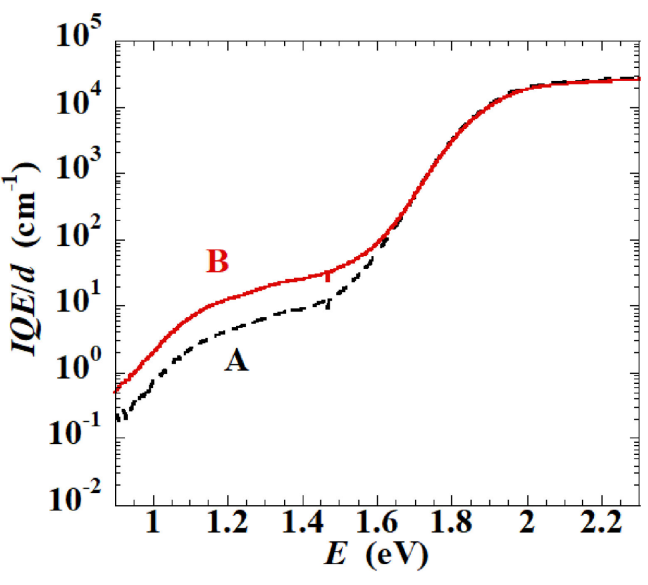

Fig. $6 \mathrm{IQE} / \mathrm{d}$ spectra for $\mathrm{a}-\mathrm{SiO} \mathrm{X}_{\mathrm{X}}: \mathrm{H}$ thin-film solar cell sample before and after light irradiation. The $\mathrm{O} /(\mathrm{Si}+\mathrm{O})$ of the i-layer in the solar cell sample was $9.2 \%$. The light irradiation time was $240 \mathrm{~min}$. The spectra A (dashed curve) and B (solid curve) represent IQE/d spectrum before and after light irradiation, respectively.

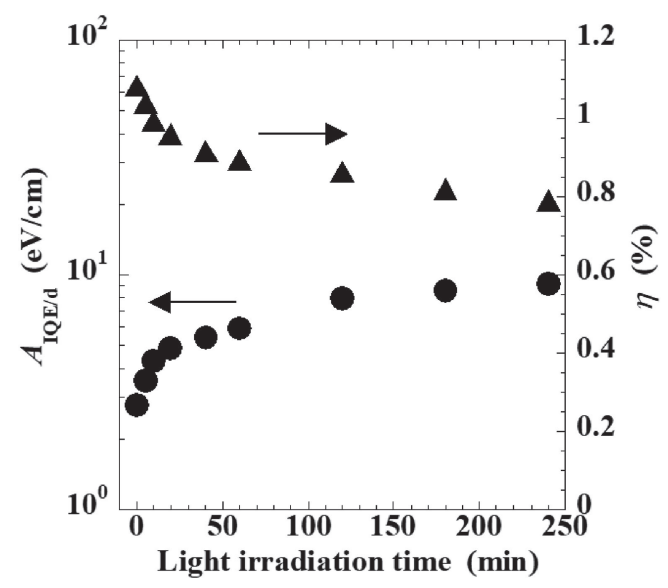

Fig. 7 Dependence of $A_{\mathrm{IQE} / \mathrm{d}}$ and conversion efficiency $\eta$ on light irradiation time in a-SiO $\mathrm{X}: \mathrm{H}$ thin-film solar cell. The $\mathrm{O} /(\mathrm{Si}+\mathrm{O})$ of the i-layer in the solar cell sample was $9.2 \%$. Circles and triangles were $A_{\mathrm{IQE} / \mathrm{d}}$ and $\eta$, respectively.

light irradiation time in the solar cell sample. Here, the $\mathrm{O} /$ $(\mathrm{Si}+\mathrm{O})$ of the i-layer in the solar cell sample was $9.2 \%$. Circles and triangles were $A_{\mathrm{IQE} / \mathrm{d}}$ and $\eta$, respectively. In Fig. 7, $A_{\mathrm{IQE} / \mathrm{d}}$ increased and $\eta$ decreased with increasing the light irradiation time. Therefore, the decrease in the $\eta$ was related to the increase in the $A_{\mathrm{IQE} / \mathrm{d}}$. The change in the $\eta$ indicates that light-induced degradation was occurred in a$\mathrm{SiO}_{\mathrm{X}}: \mathrm{H}$ thin-film solar cells. The light-induced degradation in a-SiO ${ }_{\mathrm{X}}: \mathrm{H}$ thin-film solar cell would be related to the change in $A_{\mathrm{IQE} / \mathrm{d}}$. Figure 8 shows the dependence of $E_{\mathrm{U}}$ on the light irradiation time in the solar cell sample. Here, the $\mathrm{O} /(\mathrm{Si}+\mathrm{O})$ of i-layer in the solar cell sample was $9.2 \%$. The $E_{\mathrm{U}}$ was obtained from IQE/d spectra. In Fig. 8, the $E_{\mathrm{U}}$ increased with increasing the light irradiation time and the tendency of change in $E_{\mathrm{U}}$ was similar to that in $A_{\mathrm{IQE} / \mathrm{d}}$. Therefore, the change in $E_{\mathrm{U}}$ by light irradiation would be also related to the light-induced degradation in $\mathrm{a}-\mathrm{SiO}_{\mathrm{X}}: \mathrm{H}$ thin-film solar cells. In a-Si:H films, change of absorption coefficient spectra by light irradiation has been investigated using PDS. However, the change in $E_{\mathrm{U}}$ was not observed in a-Si:H. For comparison, the change in $A_{\alpha}$ and photoconductivity $\sigma_{\mathrm{p}}$ by light irradiation 


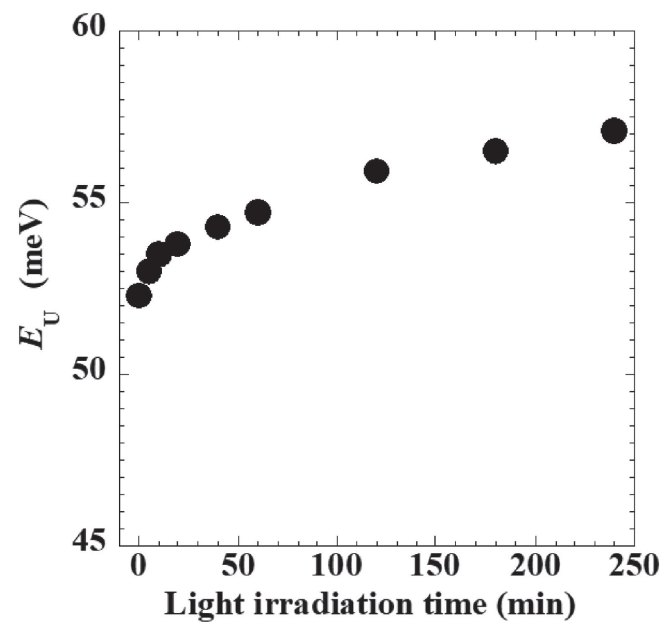

Fig. 8 Dependence of $E_{\mathrm{U}}$ on light irradiation time in a-SiO $\mathrm{X}: \mathrm{H}$ thin-film solar cell. The $\mathrm{O} /(\mathrm{Si}+\mathrm{O})$ of the i-layer in the solar cell sample was $9.2 \%$. The $E_{\mathrm{U}}$ was obtained from IQE/d spectra.

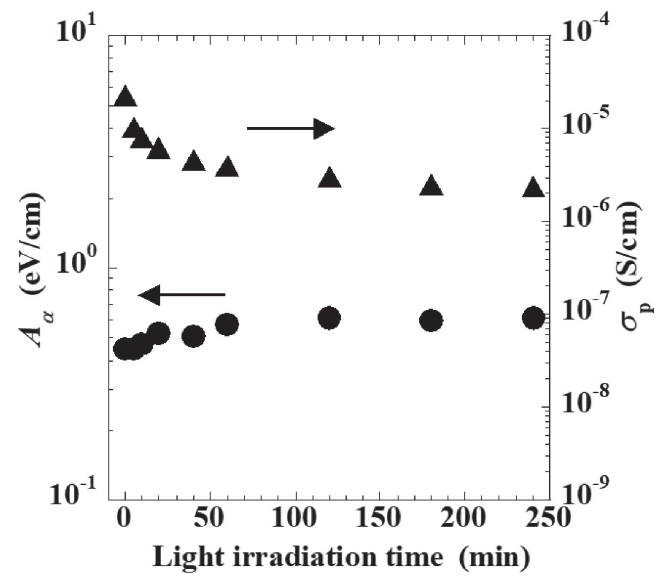

Fig. 9 Dependence of $A_{\alpha}$ and photoconductivity $\sigma_{\mathrm{p}}$ on light irradiation time in $\mathrm{a}-\mathrm{SiO}_{\mathrm{X}}: \mathrm{H}$ film. The $\mathrm{O} /(\mathrm{Si}+\mathrm{O})$ of the film sample was $9.7 \%$. Circles and triangles were $A_{\alpha}$ and $\sigma_{\mathrm{p}}$, respectively.

in film sample was also investigated. Figure 9 shows the dependence of the $A_{\alpha}$ and $\sigma_{\mathrm{p}}$ on the light irradiation time in the film sample. Here, the $\mathrm{O} /(\mathrm{Si}+\mathrm{O})$ in the film sample was 0.97. Circles and triangles were $A_{\alpha}$ and $\sigma_{\mathrm{p}}$, respectively. In Fig. 9, the $A_{\alpha}$ increased and the $\sigma_{\mathrm{p}}$ decreased with increasing the light irradiation time. Although the result was not shown, the changes in $A_{\alpha}$ and $\sigma_{\mathrm{p}}$ in the film sample with the $\mathrm{O} /$ $(\mathrm{Si}+\mathrm{O})$ of 0.87 was similar to those with the $\mathrm{O} /(\mathrm{Si}+\mathrm{O})$ of 0.97 . Although the $\mathrm{O} /(\mathrm{Si}+\mathrm{O})$ of the i-layer film in the solar cell sample was not same as those of film samples, the change in the $A_{\mathrm{IQE} / \mathrm{d}}$ by light irradiation was similar to that in the $A_{\alpha}$. Therefore, the light-induced degradation in a- $\mathrm{SiO}_{\mathrm{X}}: \mathrm{H}$ thin-film solar cell was caused by that in $\mathrm{a}-\mathrm{SiO} \mathrm{X}_{\mathrm{X}} \mathrm{H}$ i-layer. In order to understand further the cause of light-induced degradation in $\mathrm{a}-\mathrm{SiO}_{\mathrm{X}}: \mathrm{H}$ thin-film solar cell, ESR spectra time dependence for $\mathrm{a}-\mathrm{SiO}_{\mathrm{X}}: \mathrm{H}$ films and analysis on the results are necessary.

In previous report, the ESR spectrum for $\mathrm{a}-\mathrm{SiO}_{\mathrm{X}}: \mathrm{H}$ film is composed of two peaks with $g$-values of around 2.01 and 2.005 . The spin density obtained from ESR peak with $g$-value of around 2.01 is almost constant independent of $\mathrm{O} /(\mathrm{Si}+\mathrm{O})$. On the other hand, the spin density obtained from ESR peak

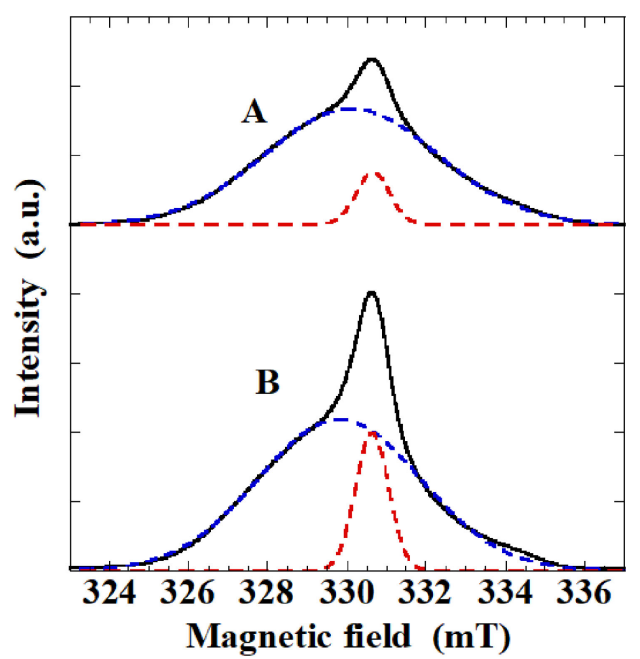

Fig. 10 ESR spectra for the $\mathrm{a}-\mathrm{SiO} \mathrm{X}_{\mathrm{X}}: \mathrm{H}$ film before and after light irradiation. The $\mathrm{O} /(\mathrm{Si}+\mathrm{O})$ of the film sample was $9.7 \%$. The light irradiation time was $240 \mathrm{~min}$. Solid lines are ESR spectra measured experimentally and dashed lines are ESR peaks obtained by peak separation. Curves A and B were ESR spectra before and after light irradiation, respectively.

with $g$-value of 2.005 depends on $\mathrm{O} /(\mathrm{Si}+\mathrm{O})$ and $A_{\alpha}$ increases with increasing spin density obtained from ESR peak with $g$-value of 2.005 due to $\mathrm{Si}$ dangling bond. ${ }^{12)}$ However, changes in the spin densities obtained from ESR peaks with $g$-values of around 2.01 and 2.005 by light irradiation were unknown. Therefore, change in ESR spectrum for the film sample was investigated. Figure 10 shows ESR spectra in the film samples before and after light irradiation. Here, the $\mathrm{O} /(\mathrm{Si}+\mathrm{O})$ of the film sample was 0.97 and the light irradiation time was $240 \mathrm{~min}$. Curves A and B were ESR spectra before and after light irradiation, respectively. The ESR spectra before and after light irradiation was composed of two peaks with $g$-values of around 2.01 and 2.005 shown by blue and red dashed lines, respectively. Therefore, the dependence of spin densities $N_{\mathrm{S}}$ obtained from the peaks with $g$-values of around 2.01 and 2.005 on light irradiation time was investigated. The obtained result is shown in Fig. 11. The triangles and circles represent $N_{\mathrm{S}}$ obtained from ESR peaks with $g$-values of around 2.01 and 2.005 , respectively. The $N_{\mathrm{S}}$ obtained from the ESR peak with the $g$-value of around 2.005 increased with increasing the light irradiation time. On the other hand, the $N_{\mathrm{S}}$ obtained from the ESR peak with the $g$-value of around 2.01 was almost constant against the light irradiation time. The ESR peak with $g$-value of 2.005 is associated with $\mathrm{Si}$ dangling bonds. We previously reported that the $A_{\alpha}$ increased with increasing the $N_{\mathrm{S}}$ due to Si dangling bond. ${ }^{12)}$ Compared with Figs. 9 and 11, the increase in $A_{\alpha}$ and decrease in $\sigma_{\mathrm{p}}$ were caused by the increase in $N_{\mathrm{S}}$ obtained from ESR peak with $g$-value of around 2.005. Therefore, the cause of lightinduced degradation in $\mathrm{a}-\mathrm{SiO}_{\mathrm{X}}: \mathrm{H}$ is the creation of $\mathrm{Si}$ dangling bonds, as in the case of a-Si:H. Based on these results, IQE/d spectrum in lower-photon-energy region would be related to the gap-state defect due to $\mathrm{Si}$ dangling bond. Therefore, light-induced degradation in $\mathrm{a}-\mathrm{SiO} \mathrm{X}_{\mathrm{X}}: \mathrm{H}$ thinfilm solar cell would be creation of Si dangling bonds in i-layer. As shown in Fig. 8, the $E_{\mathrm{U}}$ obtained from IQE/d 


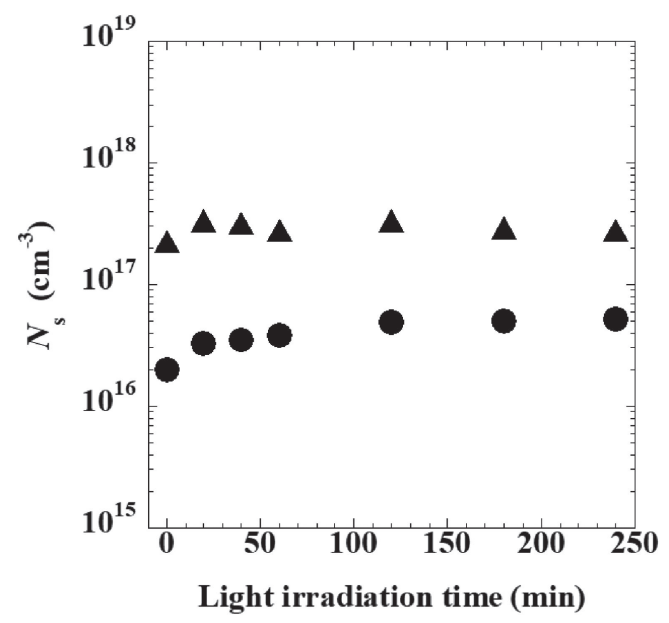

Fig. 11 Dependence of spin densities $N_{\mathrm{S}}$ obtained ESR peaks on light irradiation time in $\mathrm{a}-\mathrm{SiO}_{\mathrm{X}}: \mathrm{H}$ film. The $\mathrm{O} /(\mathrm{Si}+\mathrm{O})$ of the film sample was 9.7\%. Triangles and circles were spin densities obtained from ESR peaks with $g$-values of around 2.01 and 2.005, respectively.

spectra increased with increasing light irradiation time. In a-Si:H, light-induced volume change is detected experimentally. ${ }^{25-27)}$ The light-induced volume change would be related to light-induced degradation in a-Si:H. As Si dangling bond density increases, the structural change would occur in a$\mathrm{SiO}_{\mathrm{X}}: \mathrm{H}$. Therefore, the increase in $E_{\mathrm{U}}$ obtained from IQE/d spectra suggests that the structural change would occur in i-layer by light irradiation, because the $E_{\mathrm{U}}$ corresponds to structural randomness.

On the basis of above results, defect characterization of a-SiO ${ }_{\mathrm{X}}: \mathrm{H}$ i-layer within solar cell structure is possible using FTPS.

\section{Conclusion}

We have measured IQE spectrum for $\mathrm{a}-\mathrm{SiO}_{\mathrm{X}}: \mathrm{H}$ thin-film solar cells, in which a-SiO $\mathrm{X}: \mathrm{H}$ photo-absorber layer (i-layer) with various $\mathrm{O}$ composition ratios, by FTPS. The $E_{\mathrm{O}}$ of $\mathrm{a}-\mathrm{SiO}_{\mathrm{X}}: \mathrm{H}$ photo-absorber layer is successfully estimated from IQE spectra. IQE/d spectrum related to both the exponential tail and to gap-state defect in $\mathrm{a}-\mathrm{SiO}_{\mathrm{X}}: \mathrm{H}$ i-layer within solar cell structure are observed. We also have investigated the light-induced degradation in $\mathrm{a}-\mathrm{SiO}_{\mathrm{X}}: \mathrm{H}$ photo-absorber layer within solar cell structure by FTPS. Light-induced degradation in $\mathrm{a}-\mathrm{SiO}_{\mathrm{X}}: \mathrm{H}$ photo-absorber layer within solar cell structure is observed. Change in $E_{\mathrm{U}}$ related to light-induced structural change is also observed. By ESR measurement, the light-induced degradation in $\mathrm{a}-\mathrm{SiO}_{\mathrm{X}}: \mathrm{H}$ is caused by creation of Si dangling bonds.

Based on these results, evaluation of $\mathrm{a}-\mathrm{SiO}_{\mathrm{X}}: \mathrm{H}$ photoabsorber layer within solar cell structure is possible by FTPS measurement.

\section{Acknowledgments}

Authors would like to thank Prof. M. Konagai of Tokyo City University and Dr. S. Sugiyama of Sharp co. for their sample preparation and fruitful discussion.

\section{REFERENCES}

1) S. Inthisang, T. Krajangsang, I.A. Yunaz, A. Yamada, M. Konagai and C.R. Wronski: Phys. Status Solidi C 8 (2011) 2990-2993.

2) S. Fujikake, H. Ohta, A. Asano, Y. Ichikawa and H. Sakai: Proc. MRS 258 (1992) 875-880.

3) S. Fujikake, H. Ohta, P. Sichanugrist, M. Ohsawa, Y. Ichikawa and H. Sakai: Optoelectronics-Devices and Tech. 9 (1994) 379.

4) S. Inthisang, B. Janthong, P. Sichanugrist and M. Konagai: Proc. 26th European Photovoltaic Solar Energy Conf., (2011) p. 2392.

5) A. Matsuda: Jpn. J. Appl. Phys. 43 (2004) 7909-7920.

6) H. Dersch, J. Stuke and J. Beichler: Appl. Phys. Lett. 38 (1981) 456458.

7) T. Shimizu, H. Sugiyama and M. Kumeda: Sol. Energy Mater. Sol. Cells 66 (2001) 203-207.

8) J. Holovský, M. Schmid, M. Struckelberger, M. Despeisse, C. Ballif, A. Poruba and M. Vaněček: J. Non-Cryst. Solids 358 (2012) 2035-2038.

9) W.B. Jackson and N.M. Amer: Phys. Rev. B 25 (1982) 5559-5562.

10) J. Holovský, A. Poruba, Z. Purkrt, Z. Remeš and M. Vaněček: J. NonCryst. Solids 354 (2008) 2167-2170.

11) M. Vanecek and A. Poruba: Appl. Phys. Lett. 80 (2002) 719-721.

12) T. Itoh, R. Katayama, K. Yamakawa, K. Matsui, M. Saito, S. Sugiyama, P. Sichanugrist, S. Nonomura and M. Konagai: Jpn. J. Appl. Phys. 54 (2015) 08KB11.

13) J. Melskens, G.V. Elzakker, Y. Li and M. Zeman: Thin Solid Films 516 (2008) 6877-6881.

14) J. Melskens, M. Schouten, R. Santbergen, M. Fischer, R. Vasudenvan, D.J. van der Vlies, E.J.V. Quaz, S.G.M. Heirman, K. Jager, V. Demontis, M. Zeman and A.H.M. Smets: Sol. Energy Mater. Sol. Cells 129 (2014) 70-81.

15) A. Bidiville, T. Matsui and K. Matsubara: J. Appl. Phys. 118 (2015) 184506.

16) S.M. Sze: Physics of semiconductor devices, Chap. 1, (John Wiley \& Sons, New York, 1981).

17) Z.A. Weinberg, G.W. Rubloff and E. Bassous: Phys. Rev. B 19 (1979) 3107-3117.

18) K. Somogyi: Phys. Status Solidi A 15 (1973) 199-205.

19) J. Tauc: Mater. Res. Bull. 3 (1968) 37-46.

20) G.D. Cody, T. Tiedje, B. Beles, B. Brooks and Y. Goldstein: Phys. Rev. Lett. 47 (1981) 1480-1483.

21) D.L. Staebler and C.R. Wronski: Appl. Phys. Lett. 31 (1977) 292-294.

22) H. Sai, T. Matsui, T. Koida, K. Matsubara, M. Kondo, S. Sugiyama, H. Katayama, Y. Takeuchi and I. Yoshida: Appl. Phys. Lett. 106 (2015) 213902.

23) S. Kim, J.W. Chung, H. Lee, J. Park, Y. Heo and H.M. Lee: Sol. Energy Mater. Sol. Cells 119 (2013) 26-35.

24) A. Janotta, Y. Dikce, S. Linder, M. Schmidt, R. Janssen and M. Stutzmann: J. Appl. Phys. 95 (2004) 4046-4059.

25) K. Shimizu, T. Shiba, T. Tabuchi and H. Okamoto: Jpn. J. Appl. Phys 36 (1995) 151.

26) T. Gotoh, S. Nonomura, M. Nishio, S. Nitta, M. Kondo and A. Matsuda: Appl. Phys. Lett. 72 (1998) 2978-2980.

27) S. Nonomura, N. Yoshida, T. Gotoh, T. Sakamoto, M. Kondo, A Matsuda and S. Nitta: J. Non-Cryst. Solids 266-269 (2000) 474-480. 